\title{
To Comment on a Pattern Asuh Development for Early Childhood Education Standing Face to Face with The Digital Era
}

\author{
Ratna Sari \\ PGRI University of Palembang, Palembang, Indonesia \\ e-mail: ratnasari2016142020@gmail.com
}

\begin{abstract}
Reality life early childhood now is connected very good and the digital.On one side the digital era are had a positive impact, but on the other hand effect out the negatives serious enough for growth early childhood in education. This is evident from the fact as follows: first, that the use of digital bring substantial negative impact for the development of the baby, addicted to the world digital make child lazy move and exertion.So it would affect in the development of the brain and of child psychology.Second, in building social interaction, children tend to weak, not interested play with peers, they absorbed the world gadgetnya.Dealing with these problems, so authority educator early childhood is very important in educate, guide and direct children that not being stuck in dependence excessive to digital media.The role of educator is focused on this effort to ensure children to use med.
\end{abstract}

Keywords: The Digital Era, The Pattern Of Asuh Development For Early Childhood Education

\section{INTRODUCTION}

It must be realized that the reality of early childhood life is now very well connected with the digital era. The digital era offers greater potential in increasing inter-activity in educational components. The digital era has had a positive impact on the world of education, although it has not produced large-scale transformation.

The digital era does not always have a positive influence on the lives of early childhood in particular and the educational environment in general. The digital era will have a positive influence if early childhood can use it wisely and with full responsibility. Likewise, if the child uses a gadget only for things that are less useful, it will have a negative influence on its growth and development.

Specifically, in an educational environment, these problems may seem trivial, but have a very negative impact on the world of early childhood. Faced with these problems, the role of parents and educators is very meaningful in assisting and directing children to use gadgets wisely and with full sense of responsibility.

\section{DISCUSSION}

Digital Era and Its Impact on Early Childhood Growth 2.1 Definition of the Digital Age According to Friedman in Tambunan (2004) the digital era is a dimension of globalization characterized by the rapid development of technology that opens the boundaries of the country so that the state is increasingly without borders. This means that the digital era is shown through the development of information technology with a variety of media.

Furthermore Schrum (2013: 90) defines the digital era as a new media. This new media is a general term used to describe the late 20th century technology. Called new because the media includes many components, namely: internet, cellular telephone, interactive television, computer games, and virtual worlds. As a new technology that is integrated into the lives of children everyday, all of 
this becomes part of their activity experience which is seen as normal and familiar.

In reality, the digital era, accompanied by the growth of diverse information media, brings great benefits in facilitating children in working on information and facilitating communication. But there is no denying that the negative effects raised are also very serious. As revealed by SyifaAmeliola and HanggaraDwiyudhaNugraha (2013) in his article "Development of Information and Technology Media on Children in the Globalization Era" first, that digital use has a significant negative impact on child development, addiction to the digital world makes children lazy to move and move on. This will affect the child's brain and psychological development. Second, in building social interaction, children tend to be weak, not interested in playing with peers, they are engrossed in the world of gadgets.

\subsection{The Right Parenting Pattern for Early Childhood Education as an Effort to Respond to the Influence of the Digital Age}

Parenting consists of two words, pattern and fostering. Patterns are systems, models or ways of working. Whereas fostering is caring for, educating, maintaining, guiding, training and helping. When combined into one, then parenting is a method or method of educating children chosen by educators in giving gifts, penalties, authority and attention. (Agustiawati, 2014: 3).

Based on the above understanding, the early childhood educator authority becomes very important in educating, guiding and directing children so as not to be trapped in excessive dependence on digital media. The role of educators is more focused on efforts to keep children from using digital media wisely and full of responsibility.

\subsection{For that reason, the right parenting style that must be pursued by educators in Early Childhood Education institutions in various classification stages of development is:}

a. Giving gadget must be adjusted to the age and stage of the child's development. Parents and children need an agreement around the use of gadgets, not to protect children but to provide the right skills when children are exposed to information from gadgets, because parents cannot always watch. Parents can do the methods below according to the age and stage of child development:

\section{Toddlers aged 1-3 years}

a. Have time limit on impressions on the gadget

b. Utilizing gadgets in audio form to add vocabulary, numbers, and songs.

c. Use programs or applications to improve prosocial behavior in children. For example, an attitude of empathy or sharing

d. Use information about various people with different backgrounds to learn about diversity.

e. Avoid gadget shows that contain elements of violence and sexuality.

f. Avoid scary programs, such as ghosts

g. Avoid programs that use indecent and aggressive language programs because children can remember and repeat them again

h. Avoid ad impressions on gadgets with content that is not appropriate for a child's age

i. Accompany and interact with parents / caregivers while using the gadget

\section{Age 4-6 years}

a. Having a collective agreement that is understood and lived by the child, monitoring its implementation, consistently applying the consequences for the violation and appreciating the child's success in carrying out the agreement

b. utilize programs / applications that educate related to school readiness. For example the introduction of letters, numbers, and basic knowledge.

c. Utilizing programs / applications that teach friendship behavior and appreciate existing differences and diversity

d. Discusses the similarities and differences of children with favorite characters that are seen through the media, with the aim of improving the skills to distinguish between bad and good things

e. Avoiding programs that are nervous with violence and sexuality

f. Avoiding the usual gadget programs for gender recognition and deviation

g. Avoid gadget programs / shows that show characters solve problems with violence

h. Guiding children to know what is fact and fantasy 


\section{CONCLUSION}

The digital era does not always have a positive influence on the lives of early childhood in particular and the educational environment in general. The digital era will have a positive influence if early childhood can use it wisely and with full responsibility. Likewise, if the child uses a gadget only for things that are less useful, it will have a negative influence on its growth and development.

In reality, the digital era, accompanied by the growth of diverse information media, brings great benefits in facilitating children in working on information and facilitating communication. But there is no denying that the negative effects raised are also very serious.

The authority of early childhood educators is very important in educating, guiding and directing children so as not to be trapped in excessive dependence on digital media. The role of educators is more focused on efforts to keep children from using digital media wisely and full of responsibility in accordance with the stages of development.

\section{REFERENCES}

[1] Tabunan, Sincere.(2004). Globalization dn International Trade. Jakarta: Ghalia Indonesia.

[2] Agustiawati , Isni.2004, The Influence of Foster Polah Against Student Learning Achievements. Bandung: upi.respository.upi.edu 